\title{
Mozambique's Primary Education System and the Millennium Development Goals: Challenges, Opportunities and the Way Forward
}

\section{Abstract}

(Save the Children International- Mozambique)

In order to meet the Millennium Development Goals set forth by the United Nations' Millennium Summit that took place in 2000, in New York, particularly in the area of education, the Mozambican Government decided that, from 2003 onwards, during their primary school formation, students should be passed automatically even if they do not have enough intellectual capacities that justify their progress. In fact, this decision was made during a period when there were many pupils being failed, due to various reasons. After more than 15 years of its implementation, this paper aims to analyzing the results acquired from this decision, from the point of view of the quality of education. This will be done taking into account the prevailing situation of education in Mozambique. Having considered these aspects, the paper will move on to presenting some of the challenges and opportunities that the country should consider in the area of education, as a way to bring about better outcomes and promote development, in the country.

Key words: Education, Mozambique, Quality, Development, Millennium Development Goals.

\footnotetext{
1 João Abílio Lázaro is a Mozambican lecturer and researcher working at ISCED Open University in Mozambique. He holds a Ph.D. in Humanities from the Pontifical Catholic University do Paraná- Brazil in partinership with the Catholic University of Mozambique, a Master's Degree in Philosophy of Education from UCL-Institute of Education- University of London and a BA Honour's Degree in Philosophy and Humanities from Arrupe Jesuit University- Zimbabwe.

${ }^{2}$ Alberto Pedro Maquia, S.J., is a Mozambican Jesuit Priest, holding a Ph.D. in Education Sciences from the Catholic University of Mozambique, a Master's Degree in Moral and Political Theology, from BerkeleyCalifornia, a BA Honours Degree in Philosophy from Instituto Santo Inácio, in Belo Horizonte-Brasil and a Diploma in Moral Theology, from Hekima Jesuit University, Nairobi-Kenya.

${ }^{3}$ Carlos António Mairoce is a Mozambican researcher, socio-humanitarian manager and mentor, holding a Master's Degree in Politics, Economics and Philosophy from Witten/Herdecke University, Germany and a BA Honour's Degree in Philosophy and Humanities from Arrupe Jesuit University, Harare-Zimbabwe.
} 


\section{Introduction}

The elaboration of any educational curriculum needs to be adjusted to the continuous socioeconomic, political and educational transformations that occur in society in seeking to provide specific answers to the challenges of the society for which the same curriculum is being designed. In this regard, the challenges that the same curriculum should aim to address are those that are, particularly, related to the labor market and the wellbeing of society as a whole (Guibundana 2013). These adjustments need to be made considering education as a social practice that aims to preparing the new generation for the improvement of human values, scientific and technical knowledge and progress as a way to constantly help them ameliorate people's wellbeing and people's living conditions (Jacinto 2015 \& Guibundana 2013).

For this purpose, elementary basic education becomes the bedrock on which this transformation needs to be built on for the formation of citizens who are capable of responding to the challenges mentioned above. This is why the government of Mozambique believes that this kind of education is meant to help its beneficiaries to become citizens who know how to turn difficulties into opportunities through the provision of an harmonious and integral formation that is beneficial to them (MINED 2003). In other words, basic primary education should help these students and future generations to build a better Mozambique, to build a new citizen who has a sharper critical capacity, accompanied with the required preparedness for him/her to discern reality and act accordingly. For these aspects to become a reality, however, there is need that basic primary education plays its role in the process of children's socialization and acquisition of basic skills for their holistic development, loaded with the values of citizenship, democracy, justice, solidarity, autonomy, among others (PCEB 2003, 16).

For this purpose, primary and adult education constitute the basis that the Mozambican Government seeks to provide to each and every citizen in light of the Constitution of the Republic of Mozambique (PCEB 2003, 16 \& C.R 1990). This education plays a fundamental role in the process of children's socialization, in the transmission of fundamental knowledge and skills such as reading, writing and calculation, much as it is meant to help them acquire some commonly accepted social values for them to live as better citizens in society (PCEB 2003).

However, looking at the achievements of the national basic education being offered in the country and the quality of the students it has produced, one realizes that the objectives that 
have been set by The Millennium Development Goals (MDGs), which have been embraced by the Mozambican Government have not helped them to acquire the expected outcomes for them to be able to read, write and make basic mathematical calculations for their social and academic growth. In order to understand the reasons behind these problems and present solutions to them this paper reflects on the National Education system of Mozambique by presenting, thereafter, its shortfalls, so that it can, later on, propose the way forward for its improvement. For this purpose, let us start by understanding the philosophy behind Mozambique's national education system.

\section{Mozambique's National Education System}

The Mozambican Education System (SNE) was introduced in 1983 through Law 4/83 of 23 March and it was revised through Law 6/92 of 6 May. However, the 16-year civil war, that started in 1976 and lasted in 1992, in the country, forced the country to get into a social, economic and cultural crisis conditioning the education curriculum's expectations because there was destruction of school infrastructures, as well as there was massive disintegration of populations, resulting in the paralyzation of more than $50 \%$ of the existing primary schools in the country (MINED 1996; INDE 1997).

According to statistical data from the Ministry of Education (MINED) (1999), in 1981, the admission rate in Primary Schools (EP1) reached 93\%, but in the following years, it dropped dramatically to $54 \%$. To curb this situation, in the context of the global development strategy, in 1995, after the civil war had ended, the Government of Mozambique adopted a National Education Policy which defined basic primary education (until Grade 7 of Primary and Adult Education) as its first priority (PCEB 2003, 13). This is why, in its Strategic Plan for Education, the Ministry of Education reaffirmed the following to be the priorities of the National Education Sector:

- Increase access of educational opportunities to all Mozambicans at all levels of the country's education system;

- Maintain and improve the quality of education;

- Develop an institutional framework (MINED 1997, 1). 
Thus, Basic Education became of paramount importance for the country's development strategy because of the following reasons, which the Government understood as being:

- A central element of poverty reduction strategy as, on the one hand, the acquisition of academic knowledge, including adult literacy, is meant to widen opportunities for citizens to access employment sustainable livelihoods to all the citizens and, on the other hand, it is designed to increase the equity of the education system (MINED 1997);

- It ensures the development of human resources, necessary for the success of the nation's economy (MINED 1997);

- It is a necessity for the effective exercise of citizenship (MINED 1997).

In this regard, much as it has been highlighted above about the importance of basic education set by the Mozambican government, as far as its objectives are concerned, based on law $n^{\circ} 6 / 92$, the following can be highlighted as being of paramount importance as well:

- To educate children for citizenship;

- To educate children for economic and social development;

- To educate children about occupational practices;

- To provide the child with an integral and harmonious development;

- To empower the child, the youth and adults with a set of standards of conduct that will make them active, responsible and exemplary members in their community;

- To encourage children, young people and adults to observe, reflect and develop a sense of autonomy and self-esteem;

- To develop in them the ability to communicate clearly in Mozambican Languages, particularly in Portuguese, be it in reading, writing and speaking;

- To promote knowledge and respect for the country's national symbols;

- To educate children, the youth and adults in the preservation and fight against drugs and in the fight against endemic and epidemic diseases such as malaria, cholera, HIV/AIDS and other sexually transmitted diseases. 
In this regard, looking closely at the objectives presented above by the National Education System, commonly called SNE, one can conclude that the SNE is designed to form a righteous and well-educated citizen. The problem with it, however, is whether during the elaboration of the same objectives, its education policy designers seriously considered the aspect related to lack of quality infrastructures as a serious element that could help students and teachers to achieve the above-established goals. As far as it can be observed, considering the war situation that has been described above, one realizes that there is a missing link between the ideal type of educations aims, set above, and the reality of the country on the ground, in terms of infrastructures, for students to successfully accomplish their tasks in their learning process. The other problem, which still persists until today is that most of its teachers lack sufficient skills for them to handle the basic knowledge that should be passed on to primary school pupils. This is why it is urgent for the agents involved in the curriculum elaboration, at the Government level, to address these problems for the wellbeing not only of the education system per se, but also for the wellbeing of the country as a whole. Nevertheless, considering the need of reflecting these problems in depth, let us, in the following paragraphs, analyze the existing contradictions between progression and quality of basic education, in Mozambique.

\section{Progression vs quality of the outcome in basic education}

As it has been observed above, the Mozambican government has always supported students' progression in education. By 1980 , five years after independence, the adult literacy percentage was at about $27 \%$ in the whole country ${ }^{4}$. This percentage was due to the fact that different from English and French colonies, education was not a priority for the Portuguese colonial administration in Mozambique. Contrary to British colonies, for instance, the Portuguese only educated the Mozambican population up to Grade 4, enough for one to communicate be it orally or in writing, in Portuguese. This is why after independence in 1975, the newly formed Government, under Samora Machel, struggled to set up a massive and good quality education system that would help to address the problems that were being faced by then, in the country. Apart from this challenge, in the following years, Mozambique underwent a bloody Civil War that started in 1976 and ended in 1992, as it has been

\footnotetext{
${ }^{4}$ Illiteracy rate in 1975 was at about $97 \%$. In 1980 the rate had fallen to about $27 \%$. However, the most recent data (2017) shows that the adult literacy rate has not gone beyond $61 \%$, when in 2015 , it was of $60 \%$. https://knoema.com/atlas/Mozambique/topics/Education/Literacy/Adult-literacy-rate and http://www.ine.gov.mz/iv-rgph-2017/mocambique/apresentacao-resultados-do-censo-2017-1.
} 
mentioned above, which worsened and deteriorated the educational sector in the country. This is why, in order to ensure that, in the end, there would be high literacy rates, in 2003, the Mozambican Government embraced the Millennium Development Goals (MDG) and discouraged its teachers from failing students even if these had not acquired enough knowledge for that purpose ${ }^{5}$.

When the aspect of progression was introduced in primary school education, in Mozambique, education policy makers were particularly concerned about the turnout of students, while disregarding the sustainability aspect of the concept. As argued by the World Bank (2005), the promotion of massive education requires the removal of fees as well as it requires the inclusion of the least disadvantaged people and women in education (World Bank 2005). This is what, in fact, the Government of Mozambique did at its best in implementing such policies. However, the overwhelming number of pupils' enrolment, in Mozambique, uncovered a new dilemma to the education stakeholders as it became clear that high pupil enrolment rates were a challenge to the school infrastructures which were not prepared for that purpose, as compared to the small number of qualified existent teachers.

This challenge interfered with progression in that the ration teacher vs pupils in schools, was above the current situation of 65 students for one teacher, which makes it impossible for pupils to be given enough time to interact with their teachers and properly learn as they should. In fact, it is technically impossible for one teacher to monitor and follow up to more than 65 pupils per day. This means that most pupils are not able to properly follow their daily lessons, yet, at the end of the year, they are expected to progress to the next level of their academic life, even if this is to be done at the expense of them not having accomplished the minimum expected requirements. In fact, some years after these policies were implemented, classrooms became crowded and output factors became evident as many pupils failed to develop elementary cognitive and important skills for them to get employment (UNESCO $2010 b)$. In this regard, this constitutes one of the major stumbling blocks that calls for more reflection about the implementation of the MDGs, particularly in the area of primary education, in Mozambique.

The second problem related to students' progression in trying to help the country meet the MDGs in the area of education has to do with school infrastructures. In most of the Government primary schools in the country, particularly those located in the outskirts of the

\footnotetext{
${ }^{5}$ The $2^{\text {nd }}$ Millennium Development Goal reads: Achieve universal primary education.
} 
cities and/or in rural areas, many pupils study outside the classrooms or they have mixed classes with the same teachers. In fact, lack of proper school infrastructures is, perhaps, one of the most serious problems that is still affecting the education sector in Mozambique (JICA 2015). The system does not have enough classrooms, particularly in rural areas, to accommodate students for 8 hours a day. This is why, in some areas, many pupils study either in phases and, in most situations, they spend less than four hours at school premises or they have to study under the shadows of the available trees that grew in school premises. In this regard, one could argue that the time mentioned above is not sufficient to train a pupil who is intended to progress from one level to another at the end of the academic year (UNICEF 2017).

Nevertheless, according to Jornal "O País" (2011), despite of the criticisms levelled by Catholic Bishops against the poor quality of education, in Mozambique, it is noteworthy to recognise the efforts implemented by the Mozambican Government in the pursuit of meeting the MDGs by constructing more buildings and schools and by providing the required materials for this purpose. However, a lot still needs to be done. For instance, in order to respond to the problems mentioned above, the Government of Mozambique decided that in terms of organization, primary school timetables should be divided into two or three periods as illustrated in the tables below:

Table 1. Distribution of learning hours into two periods for two groups of students ${ }^{6}$

\begin{tabular}{|l|l|}
\hline Morning (Period 1) & Afternoon (Period 2) \\
\hline Time & Time \\
\hline $7: 00-7: 45$ & $12: 30-13: 15$ \\
\hline $7: 50-8: 35$ & $13: 20-14: 05$ \\
\hline $8: 40-9: 25$ & $14: 10-14: 55$ \\
\hline $9: 45-10: 30$ & $15: 15-16: 00$ \\
\hline $10: 35-11: 20$ & $16: 05-16: 50$ \\
\hline $11: 25-12: 10$ & $16: 55-17: 40$ \\
\hline
\end{tabular}

Table 2: Distribution of learning hours into three periods for three groups of students ${ }^{7}$

6 Source: Objectivo do programa do Governo para o quinquénio 2010-2014. Available online on http://www.mined.gov.mz/DN/INSP/Documents/OTEO\%27s2010-2014.pdf.

7 Source: Objectivos do programa do Governo para o quinquénio 2010-2014. Available online on http://www.mined.gov.mz/DN/INSP/Documents/OTEO\%27s2010-2014.pdf 


\begin{tabular}{|l|l|l|}
\hline Time & Time & Time \\
\hline Period 1 & Period 2 & Period 3 \\
\hline $6: 40-7: 20$ & $10: 40-11: 20$ & $13: 55-14: 35$ \\
\hline $7: 25-8: 05$ & $11: 25-12: 05$ & $14: 40-15: 20$ \\
\hline $8: 10-8: 50$ & $12: 10-12: 50$ & $15: 25-16: 05$ \\
\hline $9: 05-9: 45$ & $13: 05-13: 45$ & $16: 20-17: 00$ \\
\hline $9: 50-10: 30$ & & $17: 05-17: 45$ \\
\hline
\end{tabular}

Academically, however, this means that the time and attention that should be given to a particular group of students has to be distributed to two or three groups of students. This, in a way, reduces the quality of education that the three groups should receive. In this regard, to solve the above-mentioned problems, there is need for the Government of Mozambique to build more and enough schools to ensure that every student spends more than eight hours at school for him/her to receive a quality education, as a means to accomplish the MDGs in terms of providing quality primary education to everyone, and as a way to accomplish the goals that the Ministry of Education establishes for its students, in the country.

In fact, the issue of progression does not gather consensus among Mozambican families for various reasons. While the government supports its practice, there grows in the Mozambican society, the understanding that pupils, in public schools, are not learning as much as they should (Alderuccio 2010). This problem should be understood from two different perspectives. First, this should be understood from a parents' and society's perspective which supports the claim that the current progression and education system is not efficient and relevant to the Mozambican society (Alderuccio 2010). The only indicator parents and society use to support this contention is because most primary school graduates fail to fluently read and write (Alderuccio 2010). Additionally, most primary school graduates currently do not have the expected cognitive skills to interpret simple codified texts (Alderuccio 2010). Moreover, their knowledge of elementary mathematics is very limited and actually most pupils hate mathematics (Alderuccio 2010). To many parents this constitutes enough evidence to support their position.

The government's perspective, on the other hand, is that progression is good in itself because no one is left behind and illiterate (Government of Mozambique 2006). In fact, national and international official reports state that illiteracy, in Mozambique, is high and in order to meet the MDGs, primary schools should be accessible to all (UNESCO 2004). This 
is why many Governments all over the world want to present a good picture pretending that their countries are doing well in terms of education and in terms of meeting the MDGs (UNESCO 2004). However, most of the times, this is done at the expense of qualitative results (UNESCO 2004). In the case of Mozambique, the Government made a strategic decision to improve the turnout of pupils and, added to this, they decided that there should be progression in primary schools by avoiding to fail the pupils, in the same schools. However, this decision was not accompanied by supporting policies and quality infrastructures.

As a consequence, while the number of students increased, the number of teachers and infrastructures remained the same. This triggered a scenario where there were and still are more students available in schools but with no teachers and enough classrooms available for them. This means, for instance, that the few teachers available could not handle the increased number of pupils. In other words, Mozambican teachers, in primary schools, are unable to properly follow up and monitor their students' performance because these are many for one person to do a good job with them (VSO 2008). This is so because pupils progressing policy was adopted without a sufficient knowledge and understanding of elementary and key notions of dealing with complex issues such as the ones raised above, concerning the huge number of students.

Second, since free enrolments were not matched with infrastructure buildings, in most cities and districts of the country, most pupils studied and continue to study outdoors, usually under the shades of trees. Most of the times, this forces them to skip classes by staying at home, which prevents them from studying properly as they should, whenever there are bad weather conditions such as heat, cold and rain. For these reasons, looking at the poor quality of the education outcomes, most stakeholders ask the following questions: "is progression the major reason why education standards are falling in Mozambique?" If the answer is positive, then the next question is "why has progression worked in some countries and failed in Mozambique?" In fact, education progression is not a Mozambican initiative because this has been implemented in many other countries such as South Africa, Zimbabwe and Botswana, where no such poor outcomes have been verified (VSO 2010). Instead, these countries have a very good educational system. This proves that the problem has nothing to do with progression per se (VSO 2010). On the contrary, if sufficient conditions such as enough and qualified teachers, enough and good quality schools, good education policies among others, are put in place, progression could bring about bright and competent pupils much as it happens in other countries around the world (VSO 2010). 
For instance, many scholars think that the major problem concerning the decline of Mozambique's education quality has to do with teachers who are not well-trained and do not have good salaries (VSO 2010; VSO 2002; UNESCO 2006). For the situation of Mozambique, as it has been mentioned elsewhere in this discussion, the decision made by the Government found the sector unprepared in many ways: In the aspect of human resources, for instance, the sector did not have a sufficient number of trained teachers and professionals to monitor huge numbers of pupils coming into their classes (UNESCO 2006). In order to deal with this challenge, the Government decided to massively hire secondary schools graduates who had never received any teacher training course to close the gap which had been created by the high turnout of pupils UNESCO 2006). Moreover, untrained teachers were not given special guidance. Consequently, these contributed to the decreasing quality of primary school standards. This is why, Lázaro (2019) argues that "the poor learning outcomes that the system produces [today] diminishes intellectual contribution and economic productivity [...] since the products of this education system are unable to reflect on day-to-day life situations, as well as they are incapable of contributing meaningfully to the shaping of Mozambique's political and social agendas".

Associated with these problems, most of Mozambican primary school teachers end up being professionally uncommitted to the tasks that are entrusted to them due to lack of motivation and due to the fact that they find teaching in primary schools an easy profession that the Government provides, with which they can easily start earning a living (VSO 2010; VSO 2002; UNESCO 2006). This is why as a way to tackle the problems that primary education faces in the country, there is need not only to look at education progression as a solution. There is need to take into consideration other aspects such as those presented above as solutions to the issue related to quality primary education in trying to meet the MDGs, in Mozambique. In this regard, in order to avoid exhausting this discussion, let us now move on to understanding the steps that should be taken to solve the challenges mentioned in this discussion.

\section{Steps to be taken and the way forward}


According to Francisco Mandlate (2011), in order to improve the quality of education, in Mozambique, there is need for the implementation of profound reforms that may reflect the real needs and challenges of the country. For him, quality education improvement needs to start from the formation of more and better qualified lecturers with the required technical and human competences that are needed in the education system (Mandlate 2011). Currently, the Government of Mozambique has been providing one to three more years of formation to lecturers who have got their grade 10 completed as a way for them to teach students from grade one to nine (Ministério da Educação e Desenvolvimento Humano 2019). Moreover, the same has been observed in the provision of three more year of formation to those who have got their grade 12 completed, in order for them to teach students from grade ten to twelve, as well (Ministério da Educação e Desenvolvimento Humano 2019).

However, considering that in 2018, through Decreto № 46/2018, published on 1 August 2018, the Government of Mozambique decided, in article 8, that "o ensino superior realizase com docentes altamente qualificados, habilitados com o grau académico de Doutor, na sua área técnica ou artística onde se candidatam para leccionar", meaning that university education and any other kind of higher learning, in the country, should be provided by lecturers who are Ph.D. holders in their areas they intend to teach, the same Government should also impose rules in which only people with the minimum academic level of Masters' Degree holders should teach in secondary schools and BA Honours Degree holders should teach in primary schools. This would help to improve the quality of education in that instead of education being provided by people who only have their secondary school education completed, this would be provided by people who hold higher education degrees, and hence, better prepared for these particular responsibilities. This move, however, would need to be followed by other reforms, particularly in relation to salaries, incentives and other benefits that should be attributed to such professionals so as to motivate and attract them to embrace the education sector with more responsibility and develop serious work in the same sector (Serra 2010).

The second solution has to do with the abandonment of the Government's progression policy for it to be replaced by another in which each and every student passes to the next level of his/her academic formation by merit for having successfully passed the previous one, as it used to be in the past. In fact, considering that primary and secondary education are the foundation of any country's education system and yet, this foundation is shallow, in Mozambique, one might not expect that the products of this education system may positively contribute to the development of the country and provide reasonable solutions to them, in 
the future. This is because, as Lázaro (2019) argues it, "in most situations, such students simply earn diplomas and certificates which attest that they have done a particular course or formation, yet, when they are called upon to act and or intervene in their areas of study to a level that justifies the academic or non-academic formation they claim to have, most of them are unable to do so". This means that an investment in a quality education, which, in essence, is a difficult task, is what should be followed by the Mozambique government for being an assurance for both citizens and policy makers of building a better and secure future be it for improving the living conditions of the citizens and of the country.

Alternatively, if the idea of progression is to be continued, there is need to put into place the necessary conditions that have been mentioned above, otherwise, Mozambique's primary education system will continue producing citizens who will be failed professionals, incapable of accomplishing what is expected from them in future. In other words, if conditions are not put in place to change or improve the situation, the country is not only preparing failed professional for itself, but it is also paving the way and condemning itself to become a failed country/state in the future. This is because the primary education system being provided in the country is not adequately preparing its citizens to meet the demands of society and those of a labour market that requires highly qualified professionals capable of developing their tasks with independent thinking, responsibility and creativity. On the contrary, one can notice, for instance, that it is frequent to find, in the country, university students who are unable to read and write correctly as it should be expected from them, and yet, after completing their tertiary education, these are expected to get employments on the basis of their academic and non-academic areas of formation.

Based on Lumumba's (2015) observation about African education, however, Lázaro (2019) notices that the result of the education system resulting from the implementation of the MDGs, in Mozambique's education system will lead the country to the situation being lived by some African countries that have got "schools and universities that have been producing engineers but most of its roads are not being made by local civil engineers. It is the Chinese making those roads". The same situation is observed in the health sector, and many others, where, for instance, these countries have trained a lot of medical doctors in some of its schools, but when many of its wealthy people, particularly those from the political elite fall sick, these do not get treatment in their countries. They travel to foreign countries where there is a solid and quality formation system in the health sector for treatment (Lumumba 2015 apud Lázaro 2019). The most unfortunate part of it, however, is when some African political leaders are forbidden from traveling abroad for treatment because of political and 
economic crimes committed by them. These end up being condemned to rot in their own countries with their bags of money and yet, at the same time, they cannot be treated by their own countrymen because they did not create the required conditions, be it in the education, be it in the health sector, for that to happen. This means that, despite the situation described above, this is an evidence that the same people who design education policies do not trust the education system that they have, themselves, implemented in their countries (Lumumba 2015 apud Lázaro 2019). This being the case, there is need either to abandon the primary education system prevailing in the primary, which allows everyone to pass from one level to another without necessarily having developed the required academic skills and qualifications for them to be awarded a particular academic level, or there is need to ascertain, first that some basic conditions, discussed above, are put into place before continuing with the kind of primary education being offered in the country.

The second step that may help the country to improve the quality of its education system is to expand the number of hours in which students remain in school premises for them to be provided with extra-curricular activities that may help them improve their intellectual capacities. In this regard, instead of them spending only few hours at school premises, conditions should be created for pupils to spend the whole morning and afternoon in school premises for the purposes stated above, during working days. According to Adelson Rafael (2010), however, this may not necessarily imply the improvement of the quality of education since there will be need for this to be accomplished by the adoption of other necessary elements that may help to promote in them a better common living. This means that such changes should be accompanied by a new government vision concerning the role that schools should play in the life and formation of the human person in our society. In this regard, apart from the needed extra hours mentioned as a means to improve the quality of education, in schools, the same hours should be used to help the pupils develop the values of what it means to be a good student, a good son or daughter, a good community member and hence, a good citizen. Such an education should help both teachers and students to explore areas such as culture, arts, leisure, collective organization and collective decision making in improving their lives and the life of the community in which they live, as well as this should help them to improve the living conditions of other citizens and community affairs as well (Rafael 2010).

This situation, however, may need to be accomplished by including the need for an investment in infrastructures and in improving the quality of the primary school teachers' formation and their salaries, as it has been previously discussed in this paper. By improving 
the quality of primary school teachers, this paper means that if through Decreto 46/2018, the Government of Mozambique decided that higher learning should be provided by Ph.D. holders, the same should be done for secondary schools so that its students would be taught by Masters Degree professionals, while pupils in primary schools, pupils should be taught by professional who have got the minimum qualification of BA Honours Degree. That is why, this will require that the government invests in providing better salaries to these professionals, as well as these should be provided with better working conditions and promotions so as to attract them to the areas of work that they will have embraced.

\section{Conclusion}

This paper aimed to discussing the Mozambican Government's decision concerning students' progression in primary school as a way to ensure the improvement of high illiteracy rates that characterized the country since it gained independence from Portugal, in 1975. Taking into consideration that it was in 2000 that the International Community encouraged its country members to adopt the Millennium Development Goals (MDGs), particularly in the area of education and, in 2004, Mozambique embraced the same policies in view of the benefits that these would bring to the country in alleviating poverty and other challenges that were particularly affecting the least advantaged people.

After more than 15 years of its implementation, this paper analyzed the outcomes of this decision and argued that these policies did not bring about the expected outcomes. It is true that the progression policy did help to fight the illiteracy rate in the country. However, its beneficiaries have not gained the expected knowledge that justifies their academic qualifications. For this reason, some suggestions have been presented as a way forward that would help the country to get out of the poor quality education standards which, instead of helping people to improve their living conditions, it will produce more people with diplomas and certificates, yet their knowledge and skills will not justify the same degrees and diplomas, thus, creating more poverty, frustration, underdevelopment and unemployment in the country, making, therefore, Mozambique to become a failed state.

\section{References}


Alderuccio, M.C. 2010. An investigation of global/local dynamics of curriculum transformation in sub-Saharan Africa with special reference to the Republic of Mozambique. Compare, Vol. 40, No. 6, December 2010 (pp 727-739)

BR. no 19, I Série. 1992. Lei 6/92 de 6 de Maio - S.N.E. Maputo: Imprensa Nacional.

Buckland, P. 2000. Making Quality Basic Education Affordable: What have we learned? New York: UNICEF. (http://www.unicef.org/education/files/costs.pdf. Last accessed on $3 / 12 / 2010)$

Serra, Carlos. 2010. Educação: O grande desafio do quinquénio. Jornal o País 22 de Janeiro.

Government of Mozambique. 2006. Strategic Plan for Education and Culture (ESSPII) 2006-2010/11. Maputo: Government of Mozambique.

Governo de Moçambique (2014). Objectivo do programa do Governo para o quinquénio 2010-2014. Available online

on http://www.mined.gov.mz/DN/INSP/Documents/OTEO\%27s2010-2014.pdf

- 2006. Plano Estratégico de Educação e Cultura.

1990. Constituição da República.

1992. Lei 6/92 de 6 de Maio.

Guibundana, D. H. 2013. Gestão da Implementação do Novo Currículo de Ensino Básico em Moçambique: O caso das Escolas do Distrito Municipal Kamaxakeni. Juíz de Fora.

Guro, M. and Weber, E. 2010. From policy to practice: Education reform in Mozambique and Marrere Teachers' Training College. South African Journal of Education, 30 (pp 245259).

INDE. 2002. Currículo local, Estratégias de implementação do EB. Maputo: INDE e MEC.

Jacinto, L. M. 2015. Análise do Subsistema do Ensino Básico em Moçambique. Available online on http://lucianoupmtz.blogspot.com/2015/07/luciano-mario-jacinto-1-analisedo $14 . \mathrm{html}$.

JICA. 2015. Study on Basic Education Sector in Africa: Mozambique. Basic Education Sector Analysis Report.

Jornal o País. 2011. Bispos Católicos atacam educação moçambicana. 27 de Junho

Lázaro, João Abílio. 2019. A Catholic Alternative for Good Education in Mozambique. In Mugo et al (eds). The Good Education and Africa's Future: Concepts, issues \& options. Paulines, Nairobi.

Mandlate, Francisco. 2011. Entrevista à STV. -Ministro de educação reconhece fraca qualidade do ensino-aprendizagem. Jornal "O Jornal o País". 21 de Janeiro.

Mate, G. 2013. Qualidade de Educação em Moçambique: Colapso ou Desafio. Maputo.

MEC. 2008. Regulamento Geral do Ensino Básico. Moçambique. 
MINED. 2003. Plano Curricular do Ensino Básico: Objectivos, Políticas, Estrutura, Planos de Estudo e Estratégias de Implementação. Moçambique.

MINED. 1995. Política Nacional de Educação (Resolução № 8/95) Boletim da República, Série ํo I № 41, 22 de Agosto.

Ministério da Educação. 2010a. Reforma do Currículo do Ensino Primário (Estudo Específico). Avaliação do Plano Estratégico para a Educação e Cultura 20062010/11.Maputo: MINED

Ministério da Educação. Novembro 2010b. Reforma da Formação de Professores do Ensino Primário (Estudo Específico).

Moçambique. 1983. Lei 4/83, de 23 de Março.

Rafael, Adelson. 2010. Tempo de permanência do aluno na escola e qualidade de educação em Moçambique. In Jornal "O País". 3 de Maio de 2010.

Takala, T. 2004. Contribution of the sector-wide approach to improvement of the quality of basic education in Mozambique. Background paper prepared for the EFA Global Monitoring

UNESCO. 2004. Education for All. The Quality Imperative. EFA Global Monitoring Report 2005. Paris: UNESCO

UNESCO. 2006. Decentralization of Education in Mozambique. Country Report at the UNESCO Seminar on EFA Implementation: 'Teacher and Resource Management in the Context of Decentralization'. ED/EPS 2006/RP 12C. Paris: UNESCO

UNICEF. 2017. Mozambique Country Programme (2017 - 2020) Education in The new Country Programme 2017-2020

VSO. 2010. Teachers Talking: Primary teachers' contributions to the quality of education in Mozambique. London: VSO

VSO. 2002. What makes teachers tick? A policy research report on teachers' motivation in developing countries. London: VSO

VSO. 2008. Listening to Teachers. The Motivation and Morale of Education workers in Mozambique. London: VSO

World Bank. 2005. Mozambique: Poverty and Social Impact Analysis. Primary School Enrolment and Retention - the Impact of School Fees. Report No. 29423-MZ. Washington: World Bank. 